\title{
Parental leave and child health
}

\author{
By: Christopher J. Ruhm
}

Ruhm, Christopher J. "Parental Leave and Child Health", Journal of Health Economics, Vol. 19, No. 6, November 2000, 931-960.

Made available courtesy of ELSEVIER: http://www.sciencedirect.com/science/journal/01676296

\section{***Note: Figures may be missing from this format of the document}

\begin{abstract}
:
This study investigates whether rights to parental leave improve pediatric health. Aggregate data are used for 16 European countries over the 1969 through 1994 period. More generous paid leave is found to reduce deaths of infants and young children. The magnitudes of the estimated effects are substantial, especially where a causal effect of leave is most plausible. In particular, there is a much stronger negative relationship between leave durations and post-neonatal or child fatalities than for perinatal mortality, neonatal deaths, or low birth weight. The evidence further suggests that parental leave may be a cost-effective method of bettering child health.

Keywords: Parental leave; Infant mortality; Child health
\end{abstract}

\section{Article:}

\section{Introduction}

Over 100 countries, including virtually all industrialized nations, have enacted some form of parental leave policies (Kamerman, 1991). Most assure women the right to at least 2 or 3 months of paid leave during the period surrounding childbirth. Proponents believe these entitlements improve the health of children and the position of women in the workplace, and need to be legislated because adverse selection under asymmetric information, or other sources of market failure, lead the market to provide suboptimal amounts of leave. Opponentscounter that the mandates reduce economic efficiency, by restricting voluntary exchange between employers and employees, and may have particularly adverse effects on the labor market opportunities of females. ${ }^{1}$ These disagreements persist, in part, because the results of requiring employers to provide parental leave are poorly understood.

Understanding the effects of parental leave is important for both Europe and the United States. Europe has been struggling with the question of whether social protections inhibit economic flexibility and employment growth (Blank, 1994; Siebert, 1997; Nickell, 1997). All Western European countries currently offer at least 3 months of paid maternity benefits but many of the policies have been instituted or significantly revised during the sample period and some nations have recently shortened the length of leave or reduced the payments provided during it Organization for Economic Cooperation and Development, 1995). By contrast, the United States did not require employers to offer parental leave until the 1993 enactment of the Family and Medical Leave Act (FMLA), and advocates (e.g. the Carnegie Task Force on Meeting the Needs

\footnotetext{
${ }^{1}$ Ruhm (1998) provides a detailed discussion of these issues.
} 
of Young Children, 1994) have argued for broadening the law to cover small establishments and provide payment during the work absence. ${ }^{2}$

A small but rapidly growing literature has examined the effects of these policies on labor market outcomes. ${ }^{3}$ By contrast, to my knowledge, only two studies provide any information on the relationship between parental leave and health.

First, using data for 17 OECD countries, Winegarden and Bracy (1995) find that an extra week of paid maternity leave correlates with a $2 \%$ to $3 \%$ reduction infant mortality rates. The accuracy of these results is questionable, however, because the estimated effects are implausibly large and are sensitive to the treatment of wage replacement during the job absence. For example, short or medium durations of leave at high replacement rates are projected to increase infant deaths in some specifications. The lack of robustness may be due to small sample sizes or limitations in the methodological approach and imply that the findings should be interpreted cautiously. ${ }^{4}$ Second, McGovern et al. (1997) indicate that time off work has nonlinear effects on the postpartum health of mothers, as measured by mental health, vitality, and role function. Specifically, short-to-moderate periods away from the job (up to 12 to 20 weeks) are associated with worse health, whereas the reverse is true for longer absences. This pattern is difficult to explain using any plausible health production function and probably does not show a causal effect. Instead, it is likely that the quadratic specification used is overly restrictive, that a nonrandom sample of women take time off work after birth, or both.

This study provides the most detailed investigation to date of the relationship between parental leave entitlements and pediatric health. Aggregate data are used for 16 European countries over the 1969 through 1994 period. The primary outcomes examined are the incidence of low birth weight and several types of infant or child mortality. Time and country effects are controlled for and additional covariates and country-specific time trends are often included to capture the effects of confounding factors that vary over time within countries. ${ }^{5}$

\footnotetext{
${ }^{2}$ The FMLA requires employers with more than 50 workers in a 75 -mile area to allow 12 weeks of unpaid leave to persons with qualifying employment histories following the birth of a child or for a variety of health problems. There are exemptions for small firms and certain highly paid workers. A number of states enacted limited rights to leave prior to the FMLA and many workers could also take time off work under the provisions of the Pregnancy Discrimination Act of 1978 or by using vacation or sick leave. See Ruhm (1997) for further discussion of the provisions and effects of the FMLA.

${ }^{3}$ Analysis of the U.S. for the period before enactment of federal legislation generally finds that time off work is associated with increases in women's earnings and employment (e.g. Dalto, 1989; Spalter-Roth and Hartmann, 1990; Waldfogel, 1997). However, this may result from nonrandom selection into jobs providing the benefit, rather than the leave itself. Recent studies attempt to overcome the selection problem by focusing on state regulations (Kallman, 1996; Klerman and Leibowitz, 1997), federal legislation (Waldfogel, 1999; Klerman and Leibowitz, 1998; Ross, 1988), or mandates in Europe (Ruhm and Teague, 1997; Ruhm, 1998). Results of this research are mixed. The preponderance of evidence suggests that leave increases female employment but possibly with a decline in relative wages for lengthy entitlements.

${ }^{4}$ The estimating equation has fewer than 70 observations and 50 degrees of freedom. In addition, the fixed-effect models employed are unlikely to adequately account for time-varying confounding factors, the definition of paid leave probably includes payments that are independent of previous employment histories, and the equations do not allow for nonlinear effects of leave durations or replacement rates.

${ }^{5} 5$ A distinction is sometimes made between "maternity leave", granted to mothers for a limited period around childbirth, and "parental leave" which permits additional time off to care for infants or young children. Both are included in the definition of parental leave used here.
} 
To preview the results, rights to parental leave are associated with substantial decreases in pediatric mortality, especially for those outcomes where a causal effect is most plausible. In particular, there is a much stronger negative relationship between leave durations and either postneonatal mortality (deaths between 28 days and 1 year of age) or child fatalities (deaths between the first and fifth birthday) than for perinatal mortality (fetal deaths and deaths in the first week), neonatal mortality (deaths in the first 27 days), or the incidence of low birth weight. Leave entitlements are also unrelated to the death rates of senior citizens, suggesting that the models adequately control for unobserved influences on health that are common across ages. Finally, the evidence indicates that parental leave may be a cost-effective method of bettering child health and that parental time is an important input into the well-being of children.

\section{Parental leave and the health of children}

The health of young children depends on many factors including: the "stock" of health capital, the level of medical technology, the price of and access to health care, household income, and the time investments of parents. As discussed below, parental leave is most likely to improve pediatric health through the last of these mechanisms. ${ }^{6}$

The stock of health capital is stochastic but also depends on previous investments and lifestyle choices (Grossman, 1972). ${ }^{7}$ However, most of these investments occur early in pregnancy and so are unlikely to be substantially enhanced by European leave policies which generally provide time off work for only a short period immediately prior to birth (usually 6 weeks). ${ }^{8}$ There could even be negative effects. Specifically, paid leave may induce some women to work early in their pregnancies in order to meet the employment requirements to qualify for it. This reduces the time available for health investments (such as early prenatal care) and could lead to higher rates of still births and mortality during the first months of life. ${ }^{9}$

Medical care can raise the stock of health capital. Intensive interventions (e.g. neonatal intensive care) are crucial for remedying deficits during the early days of life and substantially reduce neonatal mortality (Corman and Grossman, 1995; Currie and Gruber, 1997). The medical

\footnotetext{
${ }^{6}$ These reduced-form relationships can be obtained from a structural model where parents maximize the utility function $U(H, X)$, subject to the budget constraint $Y=P_{\mathrm{m}} M+P_{\mathrm{x}} X=w R+s L+N$, the time constraint $T=$ $R+L+V$, and the health production function $H(B, M, L+V, \varepsilon) . H, X, M$, and $Y$

are health of the child, other consumption, medical care, and total income. $P_{\mathrm{m}}$ and $P_{\mathrm{x}}$ are relative prices; $T, R, L$, and $V$ indicate total time, time at work, time on leave, and nonmarket time. $B$ is baseline health, e a stochastic shock, $w$ the wage rate, $s$ the payment during parental leave, and $N$ is non-earned income. Time away from work $\left(L+{ }^{V}\right)$ is assumed to be positively related to children's health.

${ }^{7}$ For example, smoking or drinking by pregnant women may impair fetal development and result in high rates of low weight births, perinatal deaths, and neonatal mortality (Chomitz et al., 1995; Frisbie et al., 1996).

${ }^{8}$ Modest benefits are possible. For instance, parental leave may facilitate bed-rest late in pregnancy, where indicated to reduce the probability of premature birth, and some countries require employers to permit lengthier absences before birth if there is a medical reason to do so.

9 The induced employment may be substantial. Ruhm (1998) estimates that a law establishing three months of fully paid leave will increase female labor supply by $10 \%$ to $25 \%$ in the year before pregnancy. Women in industrialized countries almost always obtain prenatal care prior to childbirth; however, many do not receive it sufficiently early in their pregnancy. Studies examining the determinants of birth weights or fetal and neonatal mortality therefore typically focus on whether care is provided in the first trimester, or on the number of months from the beginning of pregnancy until prenatal care is first received (e.g. Rosenzweig and Schultz, 1983; Grossman and Joyce, 1990; Frank et. al., 1992; or Warner, 1995).
} 
infrastructure and most lifestyle choices are unlikely to be affected by parental leave entitlements but may be correlated with them, and so need to be controlled for in the analysis.

Higher incomes may improve health by raising access to medical care, particularly when a substantial portion of the expenditures are paid out-of-pocket, and by increasing the purchase of other health-improving goods and services (e.g. diet, sanitation, safety). ${ }^{10}$ Rights to parental leave are likely to modestly elevate the percentage of women employed and, unless fully offset by reductions in wages or spousal labor supply, raise household incomes. However, the increase is probably quite small and so the effect on pediatric health is likely to be minimal. ${ }^{11}$

Parental leave is likely to primarily affect child health by making more time available to parents. As recognized by Becker (1981, Chapter 5), raising children is an extremely time-intensive activity. The commitments begin before birth (e.g. the need for greater sleep and adequate prenatal care) but are likely to be particularly large during the first months of life. Moreover, some important time investments present special logistical challenges for employed persons and so may be facilitated by rights to leave.

Breast-feeding is an example of one such activity. The consumption of human milk by infants is linked to better health through decreased incidence or severity of many diseases (e.g. diarrhea, lower respiratory infection, lymphoma, otitis media, and chronic digestive diseases), reductions in infant mortality from a variety of causes (including sudden infant death syndrome), and possibly enhanced cognitive development. ${ }^{12}$ However, it is often more difficult for working women to breast- feed and employment reduces both its frequency and duration (Ryan and Martinez, 1989; Gielen et al., 1991; Lindberg, 1996; Blau et al., 1996; Roe et al., 1997).

Many health ailments afflicting the very young are transitory and have little impact on long-term development. From a policy perspective, the greatest concern is for problems that have lasting effects and, in the extreme, result in death. ${ }^{13}$ For this reason, mortality rates are the primary proxy for health in the analysis below. One way to conceptualize the relationship between mortality and health is to define a minimum threshold level of health capital, $\mathrm{H}_{\min }$, below which death occurs. The expected level of health $\mathrm{H} *$ is a function of the various inputs into the health production function and realized health is defined by $H=H^{*}+\varepsilon \quad$, where s is a stochastic shock. The probability of death is:

$$
\operatorname{Pr}(\text { Mortality })=\operatorname{Pr}\left(\varepsilon \leq H_{\min }-H^{*}\right)=\Phi\left(H_{\min }-H^{*}\right),
$$

\footnotetext{
${ }^{10}$ However, the relationship between income and health is ambiguous for industrialized countries. Some studies uncover a positive association (e.g. Ettner, 1996) while others find no effect (e.g. Duleep, 1995). Ruhm (forthcoming) shows that many types of health are adversely affected by short-lasting improvements in economic conditions, with less negative or more beneficial effects for sustained economic growth. There is stronger evidence that incomes and health are positively related in developing countries (e.g. see Prichett and Summers, 1996).

${ }^{11}$ Ruhm (1998) estimates that rights to substantial leave induce a 3\% to $4 \%$ increase in female employment. This probably represents an upper bound on the rise in household income because many new mothers have working spouses or receive transfer payments. Kallman (1996) and Ruhm also provide evidence of partially offsetting wage reductions.

${ }^{12}$ See Cunningham et al. (1991) or the American Academy of Pediatrics (AAP) Work Group on Breast-feeding (1997) for reviews of the benefits of breast-feeding. The AAP recommends that infants be fed human milk for the first 12 months of life.

${ }^{13}$ Of course, even relatively minor illnesses can escalate into fatal health problems.
} 
where $\Phi($.$) is the c.d.f. of the error term. Mortality and health are therefore inversely related and$ are affected by (many of) the same determinants.

\section{Data}

The analysis uses annual aggregate data covering the 1969-1994 period for 16 nations: Austria, Belgium, Denmark, Finland, France, (the Federal Republic of) Germany, Greece, Ireland, Italy, the Netherlands, Norway, Portugal, Spain, Sweden, Switzerland, and the United Kingdom. ${ }^{14}$ Job-related leave is distinguished from social insurance payments that are independent of work histories by defining paid leave as rights to job absences where the level of income support depends on prior employment. Most of the investigation focuses on job-protected leave, where dismissal is prohibited during pregnancy and job-reinstatement is guaranteed at the end of the leave. ${ }^{15}$ A measure of "full-pay" weeks is also calculated, by multiplying the duration of the leave by the average wage replacement rate received.

The leave entitlements apply to persons meeting all eligibility criteria. This overstates actual time off work, since some individuals do not fulfill the employment requirements and others use less than the allowed absence. Qualifying conditions have not changed or have loosened over time in most countries, however, and increased labor force participation rates imply that more women are likely to meet given work requirements. Therefore, a greater share of mothers are expected to qualify for benefits at the end of the period than at the beginning and the secular increase in parental leave entitlements is probably understated. ${ }^{16}$

Unpaid leave has been incorporated into this analysis in only a limited way for two reasons. First, many employers may be willing to provide time off work without pay, even in the absence of a mandate, making it difficult to distinguish between the effects of job absences voluntarily granted by companies and those required by law. Second, the actual use of legislated rights to unpaid leave may be quite limited, particularly for the extremely lengthy entitlements now provided in some countries. Also, no attempt is made to distinguish leave available only to the mother from that which can be taken by either parent, or to model differences in take-up" rates. These restrictions should be kept in mind when interpreting the results. If within-country growth in paid entitlements is positively correlated with changes in the proportion of persons with qualifying work histories or rights to unpaid leave, the econometric estimates will combine these factors and may overstate the impact of an increase in paid leave that occurs in isolation.

\footnotetext{
${ }^{14}$ These are the same countries studied by Ruhm and Teague (1997), except that Canada has been excluded to focus on Western Europe. Gaps and noncomparabilities in the data become more severe prior to 1969 and leave policies changed little during the early and middle 1960s. I also experimented with including the United States, which did not have any paid leave entitlement during the sample period. Doing so did not materially affect the results.

${ }^{15}$ Until recently, women were generally prohibited from working during specified periods surrounding childbirth and frequently received neither income support nor guarantees of job-reinstatement. Starting in the late 1960s, maternity leave began to evolve to emphasize paid and job-protected time off work, with father's increasingly gaining rights to leave. However, vestiges of protective legislation persist, with postnatal leaves remaining compulsory in many nations and prenatal leave continuing to be required in some. See Organization of Economic Cooperation and Development (1995); Ruhm and Teague (1997); or Ruhm (1998) for additional discussion of the history of European leave policies.

${ }^{16}$ This discussion focuses on women because they take the vast majority (usually far above 95\%) of total weeks of parental leave, even when the rights extend to fathers.
} 
In 1986, Germany simultaneously lengthened the duration of job-protected leave and extended to nonworkers the income support previously restricted to persons meeting qualifying employment conditions (Ondrich et al., 1996). Using the above criteria, this would be defined as a reduction in paid leave (since payments were no longer tied to prior employment). However, such a classification seems problematic, since the duration of job-protected time off work was substantially increased in 1986 and again in later years. For this reason, data for Germany are included only through $1985 .^{17}$

Information on parental leave is from the International Labour Office's Legislative Series, their 1984 (International Labour Office, 1984) global survey on "Protection of Working Mothers", and from Social Security Programs Throughout the World, published biennially by the United States Social Security Administration. ${ }^{18}$ The wage replacement rates used to calculate full-pay weeks of leave are approximations because they do not account for minimum or maximum payments and because some nations provide a "flat rate" amount or a fixed payment plus a percentage of earnings. 19

Table 1 summarizes parental leave provisions in effect during the last year of the data (1994 except for Germany). At that time, the 16 countries offered a minimum of 10 weeks of paid leave and six nations provided rights to more than 6 months off work. Full-pay weeks ranged from 9 weeks in Greece to 58 weeks in

\footnotetext{
${ }^{17}$ Models were also estimated with German leave entitlements either assumed to remain constant (at 32 weeks) after 1985 , or increasing according to the extensions granted in subsequent years. In the first case, the estimated parental leave effects are similar to those detailed below. The second set of estimates generally yielded somewhat smaller decreases in predicted mortality.

${ }^{18}$ This is an updated version of the parental leave data in Ruhm (1998) and Ruhm and Teague (1997). Jackqueline Teague played a primary role in the initial data collection effort, as summarized in Teague (1993). The information on unpaid leave is from Ruhm and Teague (1997) and is restricted to the 1969-1988 time period.

${ }^{19}$ In most of these cases, the replacement rate is estimated as a function of average female wages, using data from various issues of the International Labour Office's Yearbook of Labour Statistics. See Ruhm (1998) for details. The schemes used in Switzerland and Britain are not easily characterized by a single replacement rate and so the rate is not calculated for these nations.
} 
Table 1

Job-protected paid parental leave in 1994

Information for Germany refers to 1985 .

\begin{tabular}{|c|c|c|c|c|}
\hline Country & $\begin{array}{l}\text { Leave } \\
\text { entitlement }\end{array}$ & Rate of pay & Source of funds & $\begin{array}{l}\text { Qualification } \\
\text { conditions }\end{array}$ \\
\hline Austria & 16 weeks & $\begin{array}{l}100 \% \text { with } \\
\text { maximum }\end{array}$ & $\begin{array}{l}\text { Payroll Taxes, } \\
\text { Government }\end{array}$ & $\begin{array}{l}\text { In covered } \\
\text { employment. }\end{array}$ \\
\hline Belgium & 15 weeks & $\begin{array}{l}78 \%(82 \% \\
\text { in first month, } \\
75 \% \text { thereafter })\end{array}$ & $\begin{array}{l}\text { Payroll Taxes, } \\
\text { Government }\end{array}$ & $\begin{array}{l}\text { Insured } 6 \\
\text { months before } \\
\text { leave. }\end{array}$ \\
\hline Denmark & 28 weeks & $\begin{array}{l}90 \% \text { with } \\
\text { maximum }\end{array}$ & $\begin{array}{l}\text { Employers, } \\
\text { Government }\end{array}$ & $\begin{array}{l}120 \text { hours of } \\
\text { employment } \\
\text { in preceding } \\
3 \text { months. }\end{array}$ \\
\hline Finland & 44 weeks & $\begin{array}{l}80 \% \text { with } \\
\text { minimum } \\
\text { lower rate at } \\
\text { high incomes }\end{array}$ & $\begin{array}{l}\text { Payroll Taxes, } \\
\text { Government }\end{array}$ & $\begin{array}{l}\text { Residence } \\
\text { in country. }\end{array}$ \\
\hline France & 16 weeks & $\begin{array}{l}84 \% \text { with } \\
\text { minimum } \\
\text { and maximum }\end{array}$ & $\begin{array}{l}\text { Payroll and } \\
\text { Dedicated Taxes }\end{array}$ & $\begin{array}{l}\text { Insured } 10 \\
\text { months before } \\
\text { leave; minimum } \\
\text { work hours or } \\
\text { contributions. }\end{array}$ \\
\hline Germany & 32 weeks & $\begin{array}{l}100 \% \text { with } \\
\text { minimum } \\
\text { and maximum }\end{array}$ & $\begin{array}{l}\text { Payroll Taxes, } \\
\text { Government }\end{array}$ & $\begin{array}{l}12 \text { weeks } \\
\text { of insurance } \\
\text { or } 6 \text { months of } \\
\text { employment. }\end{array}$ \\
\hline Greece & 15 weeks & $\begin{array}{l}60 \% \text { with } \\
\text { minimum }\end{array}$ & $\begin{array}{l}\text { Payroll Taxes, } \\
\text { Government }\end{array}$ & $\begin{array}{l}200 \text { days of } \\
\text { contributions } \\
\text { during last } \\
2 \text { years. }\end{array}$ \\
\hline Ireland & 14 weeks & $\begin{array}{l}70 \% \text { with } \\
\text { maximum }\end{array}$ & $\begin{array}{l}\text { Payroll Taxes, } \\
\text { Government }\end{array}$ & $\begin{array}{l}39 \text { weeks of } \\
\text { contributions. }\end{array}$ \\
\hline Italy & 48 weeks & $\begin{array}{l}53 \%(80 \% \\
\text { first } 5 \\
\text { months; } 30 \% \\
\text { next } 6 \\
\text { months) }\end{array}$ & $\begin{array}{l}\text { Payroll Taxes, } \\
\text { Government }\end{array}$ & $\begin{array}{l}\text { Employed and } \\
\text { insured at } \\
\text { start of } \\
\text { pregnancy. }\end{array}$ \\
\hline Netherlands & 12 weeks & $100 \%$ & $\begin{array}{l}\text { Payroll Taxes, } \\
\text { Government }\end{array}$ & $\begin{array}{l}\text { Employed and } \\
\text { insured. }\end{array}$ \\
\hline Norway & 42 weeks & $\begin{array}{l}100 \% \text { with } \\
\text { maximum }\end{array}$ & $\begin{array}{l}\text { Payroll Taxes, } \\
\text { Government }\end{array}$ & $\begin{array}{l}\text { Employed and } \\
\text { insured in } \\
6 \text { of last } \\
10 \text { months. }\end{array}$ \\
\hline Portugal & 21 weeks & $\begin{array}{l}100 \% \text { with } \\
\text { minimum }\end{array}$ & $\begin{array}{l}\text { Payroll Taxes, } \\
\text { Government }\end{array}$ & $\begin{array}{l}\text { Employed with } \\
6 \text { months of } \\
\text { insurance } \\
\text { contributions. }\end{array}$ \\
\hline
\end{tabular}




\begin{tabular}{|c|c|c|c|c|}
\hline Country & $\begin{array}{l}\text { Leave } \\
\text { entitlement }\end{array}$ & Rate of pay & Source of funds & $\begin{array}{l}\text { Qualification } \\
\text { conditions }\end{array}$ \\
\hline Spain & 16 weeks & $\begin{array}{l}100 \% \text { with } \\
\text { maximum }\end{array}$ & $\begin{array}{l}\text { Payroll Taxes, } \\
\text { Government }\end{array}$ & $\begin{array}{l}180 \text { days of } \\
\text { contributions } \\
\text { during last } 5 \\
\text { years. }\end{array}$ \\
\hline Sweden & 64 weeks & $90 \%$ & $\begin{array}{l}\text { Payroll Taxes, } \\
\text { Government }\end{array}$ & $\begin{array}{l}\text { Insured } 240 \\
\text { days before } \\
\text { confinement. }\end{array}$ \\
\hline Switzerland & 10 weeks & $\begin{array}{l}\text { varies with } \\
\text { type of } \\
\text { insurance } \\
\text { fund }\end{array}$ & $\begin{array}{l}\text { Payroll Taxes, } \\
\text { Government }\end{array}$ & $\begin{array}{l}\text { Up to } 9 \\
\text { months of } \\
\text { insurance } \\
\text { contributions } \\
\text { (depending } \\
\text { on fund). }\end{array}$ \\
\hline United Kingdom & 18 weeks & $\begin{array}{l}90 \% \text { for } 6 \\
6 \text { weeks, } \\
\text { flat rate } \\
\text { thereafter }\end{array}$ & $\begin{array}{l}\text { Payroll Taxes, } \\
\text { Employers, } \\
\text { Government }\end{array}$ & $\begin{array}{l}6 \text { months of } \\
\text { coverage } \\
\text { with minimum } \\
\text { earnings. }\end{array}$ \\
\hline
\end{tabular}

Sweden, with a slight negative correlation between replacement rates and leave durations. Income support was typically financed through a combination of payroll taxes and general revenues, although direct employer contributions were sometimes required. The conditions to be eligible for leave varied but persons with more than a year of service were usually covered.

Table 2 displays leave durations and estimated wage replacement rates for each country at 5-year intervals. The number of nations providing job-protected leave rose from eight in 1969 to 13 in 1979, with all 16 doing so after 1983. Countries supplying parental benefits in 1969 extended them subsequently, with the result that the dispersion of leave entitlements tended to increase over time. There were 38 observed changes in durations over the sample period and 12 additional cases where nations modified replacement rates without altering the length of leave.

Pediatric health is proxied in the analysis by the incidence of low birth weight and several mortality rates. The death rate of persons aged 65 and over is also used to test for omitted variables bias. Information on birth weight and perinatal deaths is obtained from the OECD Health Data 96 (Organization for Economic Cooperation and Development, 1996a). Data on neonatal, post-neonatal, infant, child, and senior citizen mortality are from the WHO Health for All Data Base: European Region (World Health Organization, 1997). ${ }^{20}$ Table 3 provides definitions and descriptive statistics for all variables used below.

\footnotetext{
${ }^{20}$ In the WHO data, child mortality refers to deaths before age 5 . This was converted into deaths between the first and fifth birthday by subtracting infant mortality rates.
} 
Table 2

Job-protected paid leave and wage replacement rates in selected years

\begin{tabular}{lllllll}
\hline Country & 1969 & 1974 & 1979 & 1984 & 1989 & 1994 \\
\hline Austria & $12[1.00]$ & $12[1.00]$ & $16[1.00]$ & $16[1.00]$ & $16[1.00]$ & $16[1.00]$ \\
Belgium & $14[0.60]$ & $14[0.71]$ & $14[0.80]$ & $14[0.80]$ & $14[0.82]$ & $15[0.78]$ \\
Denmark & 0 & 0 & 0 & $18[0.90]$ & $28[0.90]$ & $28[0.90]$ \\
Finland & 0 & $29[0.55]$ & $35[0.55]$ & $43[0.80]$ & $44[0.80]$ & $44[0.80]$ \\
France & 0 & 0 & $16[0.90]$ & $16[0.90]$ & $16[0.90]$ & $16[0.84]$ \\
Germany & $14[1.00]$ & $14[1.00]$ & $32[1.00]$ & $32[1.00]$ & & \\
Greece & 0 & 0 & 0 & $12[0.60]$ & $12[0.60]$ & $15[0.60]$ \\
Ireland & 0 & 0 & 0 & $14[0.70]$ & $14[0.70]$ & $14[0.70]$ \\
Italy & $21[0.80]$ & $31[0.80]$ & $57[0.57]$ & $48[0.53]$ & $48[0.53]$ & $48[0.53]$ \\
Netherlands & 0 & 0 & $12[1.00]$ & $12[1.00]$ & $12[1.00]$ & $12[1.00]$ \\
Norway & $12[0.13]$ & $12[0.32]$ & $18[1.00]$ & $18[1.00]$ & $24[1.00]$ & $42[1.00]$ \\
Portugal & 0 & $9[1.00]$ & $13[1.00]$ & $13[1.00]$ & $13[1.00]$ & $21[1.00]$ \\
Spain & 0 & $12[0.75]$ & $14[0.75]$ & $14[0.75]$ & $14[0.75]$ & $16[1.00]$ \\
Sweden & $16[0.55]$ & $26[0.90]$ & $39[0.90]$ & $52[0.71]$ & $52[0.71]$ & $64[0.90]$ \\
Switzerland & $10[]$. & $10[]$. & $10[]$. & $10[]$. & $10[]$. & $10[]$. \\
United Kingdom & $18[]$. & $18[]$. & $18[]$. & $18[]$. & $18[]$. & $18[]$. \\
\hline
\end{tabular}

Wage replacement rates, shown in brackets, are sometimes subject to minimums or maximums and are sometimes estimated to account for differences during early and later portions of the leave or flat rate payments. Replacement rates for Switzerland and Britain are not easily characterized.

Data limitations restrict the set of regressors included in the econometric models. The characteristics sometimes controlled for include: real per capita GDP (GDP), health care expenditures as a percent of GDP (SPENDING), the share of the population with health insurance coverage (COVERAGE), the number of kidney dialysis patients per 100,000 population (DIALYSIS), the fertility rate of 15-44 year old women (FERTILITY), and the female employment-to-population ratio (EP RATIO). ${ }^{21}$

GDP, SPENDING, COVERAGE, and DIALYSIS, referred to below as the "standard" set of regressors, are expected to be positively related to child health. Higher incomes allow greater investments in medical care and health. Holding

\footnotetext{
${ }^{21}$ Data are from Organization for Economic Cooperation and Development (1996a). Several procedures were used to fill in missing values for some variables. In particular: 1969 values for DIALYSIS were extrapolated assuming a constant growth rate between 1969 and 1971; FERTILITY for Belgium, France, Denmark, Spain, and Britain in 1969 was assumed to be the same as in 1970. Fertility in the Netherlands for 1969-1974 was set at its 1975 value. French fertility in 1971-1974 was interpolated using a linear trend between 1970 and 1975. Linear interpolation was also used for 1972-1974 in Belgium, 1976-1977 in the Netherlands, 1971-1979 in Spain, and 1972-1974 and 1978-1979 inBritain. EP RATIOS are from Ruhm (1998); Ruhm and Teague (1997) and Organization for Economic Cooperation and Development (1996b). Values in the early years for Greece, the Netherlands, Norway, and Portugal are set equal to those in the first period for which data were available (1972, 1975, 1977, and 1974, respectively).
} 
Table 3

Summary information on variables used in analysis

\begin{tabular}{|c|c|}
\hline Variable & Definition and descriptive statistics \\
\hline \multicolumn{2}{|c|}{ Outcome variables (per 1000 live births unless noted) } \\
\hline INFANT & Infant Mortality: infant deaths under 1 year $(n=414, \mu=13.2, \sigma=6.9)$ \\
\hline LOW WEIGHT & $\begin{array}{l}\text { Low Birth Weight: new-borns weighing less than } 2,500 \text { grams as \% of live births } \\
\text { and still births over } 1,000 \text { grams }(n=267, \mu=5.7, \sigma=0.77)\end{array}$ \\
\hline PERINATAL & $\begin{array}{l}\text { Perinatal Mortality: stillbirths ( } \geq 28 \text { weeks gestation) and deaths within } 1 \text { week of } \\
\text { birth per } 1,000 \text { live and still births }(n=399, \mu=15.4, \sigma=7.1)\end{array}$ \\
\hline NEONATAL & Neonatal Mortality: infant deaths under 28 days $(n=378, \mu=8.5, \sigma=4.9)$ \\
\hline POSTNEO & $\begin{array}{l}\text { Post-neonatal Mortality: deaths between } 28 \text { days and } 1 \text { year } \\
(n=378, \mu=4.3, \sigma=2.5)\end{array}$ \\
\hline CHILD & Child Mortality: deaths between 1 and 5 years of age $(n=395, \mu=2.3, \sigma=1.0)$ \\
\hline DEATH65 & $\begin{array}{l}\text { Standardized Death Rate of Persons } \geq 65 \text { years old per } 1000 \text { population } \\
(n=405, \mu=56.9, \sigma=8.5)\end{array}$ \\
\hline \multicolumn{2}{|l|}{ Other Variables } \\
\hline LEAVE & Weeks of Job-Protected Paid Parental Leave $(n=407, \mu=19.5, \sigma=13.8)$ \\
\hline PAID & $\begin{array}{l}\text { Weeks of Paid Parental Leave with or without job-protection } \\
(n=407, \mu=20.9, \sigma=12.3)\end{array}$ \\
\hline TOTAL & $\begin{array}{l}\text { Weeks of Job-Protected Paid and Unpaid Parental Leave } \\
(n=317, \mu=39.5, \sigma=33.2)\end{array}$ \\
\hline RATE & $\begin{array}{l}\text { Average wage replacement rate (in \%) during Parental Leave } \\
(n=355, \mu=79.0, \sigma=20.6)\end{array}$ \\
\hline GDP & $\begin{array}{l}\text { Real GDP per capita in thousands of } 1994 \text { U.S. dollars, adjusted using PPP and the } \\
\text { all-items CPI }(n=416, \mu=15.2, \sigma=3.4)\end{array}$ \\
\hline SPENDING & Expenditures on Health Care as Percent of GDP $(n=415, \mu=6.7, \sigma=1.5)$ \\
\hline COVERAGE & $\begin{array}{l}\text { Share of population with Health Insurance coverage } \\
(n=416, \mu=0.937, \sigma=0.096)\end{array}$ \\
\hline DIALYSIS & Number of Dialysis patients per 100,000 population $(n=416, \mu=14.0, \sigma=11.0)$ \\
\hline FERTILITY & Fertility Rate of $15-44$ year old women $(n=415, \mu=1.87, \sigma=0.43)$ \\
\hline EP RATIO & $\begin{array}{l}\text { Female Employment-to-Population Ratio: civilian employment divided } \\
\text { by the } 15 \text { to } 64 \text { year old population, using standardized OECD definitions } \\
(n=411, \mu=0.451, \sigma=0.113)\end{array}$ \\
\hline BIRTHS & Number of Births in thousands $(n=416, \mu=568, \sigma=277)$ \\
\hline
\end{tabular}

Observations are weighted by the number of births in each cell.

income constant, health is likely to improve when a greater proportion of spending is for medical care and when health insurance is common. Kidney dialysis is not anticipated to be causally related to pediatric outcomes. Rather, it proxies sophisticated medical technologies (e.g. neonatal intensive care) for which data are not available.

Female employment could affect pediatric health by changing income and nonmarket time. For instance, working women may have less time to invest in infants, leading to worse health. Similarly, several studies (e.g. Rosenzweig and Wolpin, 1988; Frank et al., 1992) suggest that fertility rates and infant deaths are positively correlated. However, these variables may be endogenous, since parental leave is often provided or extended with the goal of increasing birthrates or improving the labor market opportunities of women. ${ }^{22}$ There may also be reverse causation. Higher infant mortality rates imply, ceteris paribus, that more births are needed to achieve a target family size and that there are fewer young mothers, who have relatively low

\footnotetext{
${ }^{22}$ Averett and Whittington (1997) analysis of U.S. data indicates women working for employers providing maternity leave have modestly higher fertility rates than those who do not.
} 
rates of employment. ${ }^{23}$ Reflecting these concerns, results will be presented for models both with and without these regressors.

\section{Time trends}

Parental leave entitlements rose sharply between 1969 and 1994 . Weighting by the number of births in each cell, the mean duration of job-protected paid leave grew from 10 to 26 weeks and full-pay weeks from 8 to 21 weeks (see Fig. 1). ${ }^{24}$ The growth was most dramatic prior to 1980, with a particularly large jump occurring at the end of the 1970s when nine countries (Denmark, Finland, France, Germany, Ireland, Italy, Norway, Portugal, and Sweden) almost simultaneously extended entitlements. There has been little change in average duration since the early 1980s, as increases in some countries have offset declines in others.

Fig. 2 documents trends in the child health outcomes. Observations are displayed as percentages of 1969 values (1970 for child mortality) and are weighted by the number of births. There is no evidence that the incidence of low birth weight has fallen over time. The instability observed early in the period occurs because of missing data for several countries in some years. ${ }^{25}$ Nevertheless, even after the middle 1980s, when the information becomes more complete, there is no indication of a downward trend. ${ }^{26}$ This is not surprising. Birth weight results from a complex interaction of factors. For instance, improvements in prenatal care probably raise birth weights but this may be offset by new medical technologies that increase the survival of lowweight fetuses. Thus, birth weight provides an ambiguous measure of pediatric health and strong associations between it and parental leave are unlikely.

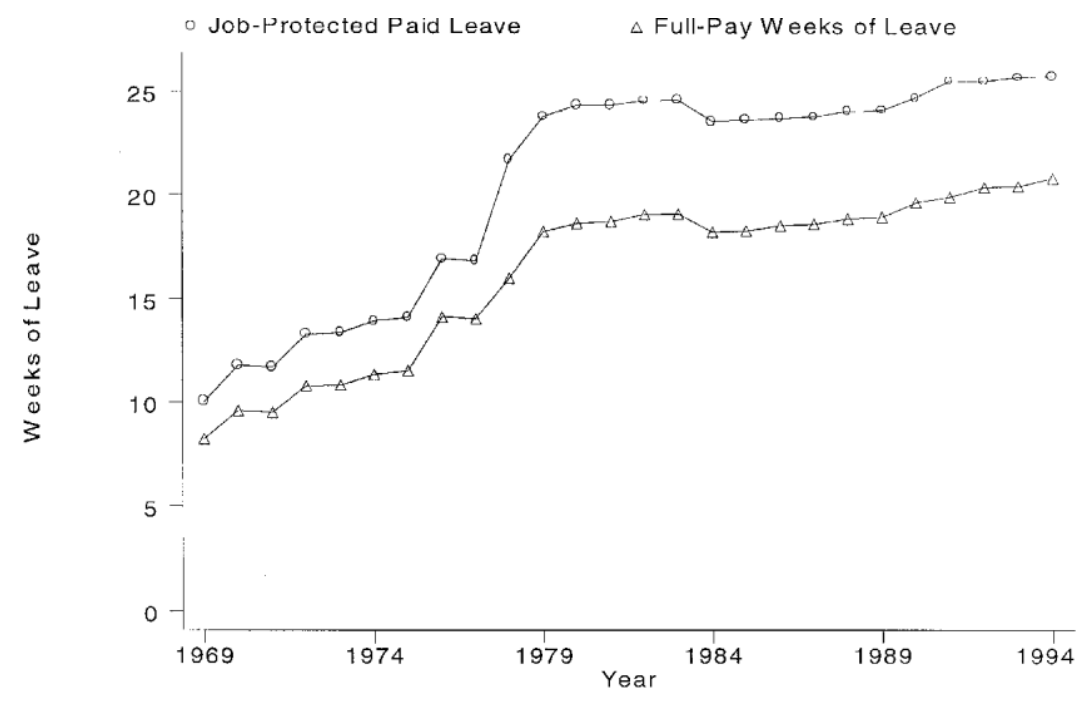

Fig. 1. Average weeks of paid parental leave.

\footnotetext{
${ }^{23}$ Browning (1992) discusses the relationship between children and female labor supply in detail.

2424 These calculations assume that German parental leave entitlements remain constant at 32 weeks after 1985 and that Swiss and British wage replacement rates equal the sample average (79\%) in all years.

${ }^{25}$ For instance, the spike in 1973 occurs because this is the only year prior to 1979 that data are available for Italy, which has relatively high rates of low-weight births. Birth weight information is also sometimes missing for Belgium, France, Germany, Greece, Ireland, the Netherlands, Portugal, Spain, Switzerland, and the United Kingdom.

${ }^{26}$ This mirrors the experience of the United States, where the incidence of low weight births rose modestly between the middle 1980s and early 1990s.
} 
By contrast, pediatric mortality has fallen dramatically since the late 1960s. Infant fatalities decreased $75 \%$ between 1969 and 1994 (from 23.4 to 6.0 per thousand live births), perinatal deaths by $71 \%$ (from 26.3 to 7.6 per thousand live and still births), and child mortality by $63 \%$ between 1970 and 1994 (from 3.4 to



Fig. 2. Trends in child health outcomes.

1.3 per thousand live births). ${ }^{27}$ Obviously, most of these reductions are unrelated to parental leave, highlighting the importance of controlling for sources of spurious correlation.

\section{Estimation strategy}

The econometric techniques are designed to account for omitted factors and cross-country differences definitions or measurement of the dependent variables. ${ }^{28}$ The basic specification is:

$$
H_{j t}=\alpha+\beta_{1} C_{j}+\beta_{2} T_{t}+\gamma X_{j t}+\delta L_{j t}+\varepsilon_{j t}
$$

where $\mathrm{H}_{\mathrm{jt}}$ is the natural $\log$ of the health outcome in country $\mathrm{j}$ at year $\mathrm{t}, \mathrm{C}$ is a nation-specific fixed-effect, $\mathrm{T}$ is a general time effect, $\mathrm{X}$ is a vector of observable determinants of health, $\mathrm{L}$ measures weeks of parental leave entitlement, and $\mathrm{s}$ is the regression disturbance. The fixedeffect holds constant all sources of unobserved time-invariant heterogeneity across nations; the time-effect accounts for sources of technological progress or other omitted determinants of health that occur across countries at the same time; and the vector of covariates controls for at least some time-varying country effects.

\footnotetext{
${ }^{27}{ }^{2}$ Neonatal deaths fell $76 \%$ (from 15.3 to 3.7 per 1000 live births) and post-neonatal mortality by $67 \%$ (from 7.1 to 2.4 per 1000 thousand live births) between 1969 and 1994. By comparison, the standardized death rate of senior citizens fell $34 \%$ (from 68.4 to 45.3 per 1000 population). Infant and child deaths trended downward in all sample countries, with somewhat larger decreases typically observed in nations with high initial fatality rates. For example, infant mortality in Portugal fell 85\% (from 55.8 to 8.1 per 1,000 live births), whereas in Sweden the decline was by $63 \%$ (from 11.6 to 4.3 per 1000 live births).

${ }^{28}$ Liu et al. (1992) document significant cross-national differences in the measurement of infant mortality.
} 
The estimated parental leave effect, $\hat{\delta}$, will be biased if $\operatorname{cov}\left(L_{j t} \varepsilon_{j t}\right) \neq 0$. This occurs if there are omitted time-varying country-specific factors $\left(C_{j} \times T_{t}\right)$ that are correlated with changes in parental leave. For instance, it is possible that nations increase entitlements at times when health is improving for other reasons (e.g. due to demographic changes or new medical technologies). One method of dealing with this will be to control for country-specific linear time trends, under the assumption that many unobserved factors exhibit a monotonic trend.

Omitted variables bias could still be a problem, however, if within-country changes in parental leave are correlated with unobservables (e.g. the diffusion of neonatal intensive care facilities) that have particularly strong impacts on the health of young children. This possibility will be addressed by examining whether the predicted "effects" of leave are stronger for outcomes (such as post-neonatal and child mortality) where parental time investments plausibly have a large impact than for those (such as perinatal and neonatal mortality) where other factors are expected to dominate.

\section{Results}

The econometric results are summarized in this section. A detailed investigation is first provided of the determinants of infant mortality. This is followed by consideration of the other outcomes

- low birth weight and perinatal, neonatal, post-neonatal, child, or senior citizen deaths. Finally, the estimating equations are modified to allow nonlinear leave effects. Vectors of country and time dummy variables are always included, additional covariates and country-specific time trends are frequently controlled for, and the dependent variables are measured in natural logs.

\subsection{Infant mortality}

Table 4 displays the results of five specifications examining the determinants of (the natural log of) the infant mortality rate. The parental leave regressor is weeks of job-protected paid leave divided by 100 . The specifications control for country 
Table 4

Econometric estimates of the effects of paid parental leave on infant mortality using linear specifications

\begin{tabular}{lccccc}
\hline Regressor & (a) & (b) & (c) & (d) & (e) \\
\hline LEAVE & -0.0996 & -0.1687 & -0.2660 & -0.2905 & -0.2451 \\
& $(0.0820)$ & $(0.0795)$ & $(0.0786)$ & $(0.0788)$ & $(0.0079)$ \\
GDP & -0.0193 & -0.0165 & & 0.0136 & 0.0083 \\
& $(0.0064)$ & $(0.0065)$ & & $(0.0069)$ & $(0.0082)$ \\
SPENDING & -0.0251 & -0.0268 & & 0.0010 & 0.0012 \\
& $(0.0095)$ & $(0.0091)$ & $(0.0086)$ & $(0.0084)$ \\
COVERAGE & -0.0076 & -0.0050 & & 0.0002 & 0.0003 \\
& $(0.0007)$ & $(0.0008)$ & & $(0.0009)$ & $(0.0009)$ \\
DIALYSIS & -0.0098 & -0.0084 & & -0.0030 & -0.0030 \\
& $(0.0011)$ & $(0.0011)$ & & $(0.0014)$ & $(0.0014)$ \\
FERTILITY & & 0.1221 & & & 0.0561 \\
& & $(0.0221)$ & & & $(0.0296)$ \\
EP RATIO & & 0.2751 & & & 0.1333 \\
& & $(0.1620)$ & & & $(0.1735)$ \\
Time trends & No & No & Yes & Yes & Yes \\
\hline
\end{tabular}

The dependent variable is the natural $\log$ of the infant mortality rate. Data are for 16 European countries over the 1969-1994 period $(n=403)$. Standard errors are shown in parentheses. All models include country and year dummy variables. The estimates in columns (c) through (e) also include country-specific (linear) time trends. Other regressors are also controlled for as shown on the table. LEAVE refers to weeks of job-protected parental leave divided by 100 .

fixed-effects and general year effects. Additional explanatory variables and country-specific time trends are also frequently included. For brevity, the national characteristics included in models (a) and (d) are referred to as "standard" characteristics, while the fertility rate and female employment-to-population ratio are denoted as "supplemental' regressors.

As expected, higher income, greater health spending, broader insurance cover-age, and increased medical technology (indicated by the frequency of dialysis) reduce predicted infant mortality rates by statistically significant amounts in the models without country-specific time trends (see columns a and $b$ ). Since these characteristics tend to change gradually over time, the associated coefficients generally become small and insignificant when country time-trends are included (specifications $\mathrm{d}$ and e). ${ }^{29}$ The time trends presumably also capture other sources of timevarying heterogeneity. There is also some evidence of a positive correlation between fertility or female employment-to-population ratios and the infant death rate.

Parental leave is estimated to have a substantial negative effect on infant mortality. For instance, a 10 -week extension in leave is predicted to decrease infant deaths by $1.0 \%$ in column (a) and $1.7 \%$ in model (b). As discussed, the inclusion of country-specific time trends is likely to be helpful in eliminating remaining sources of omitted variables bias. Thus, it is informative that the parental leave coefficient rises (in absolute value) when these are controlled for and the size of the estimated effect becomes robust across model specifications - rights to 10 extra weeks of leave reduce predicted mortality by $2.6 \%, 2.9 \%$, and $2.4 \%$ in specifications (c), (d), and (e). To place these percentage reductions in perspective, a $2.5 \%$ decrease in infant mortality corresponds to a drop in the infant death rate from 13.2 to 12.9 per thousand live births. Thus, large percentage changes imply fairly small absolute effects, since infant mortality is quite rare.

\footnotetext{
${ }^{29}$ The positive coefficient on per capita GDP is consistent with evidence provided by Ruhm (forthcoming) indicating negative health effects of transitory increases in income.
} 
Table 5 tests the sensitivity of the findings to a variety of alternative models. This table and the remainder of the analysis focuses on equations that include country-specific time trends and the standard country characteristics. Specification (b) also includes the supplemental regressors. Thus, the first row of the table restates the findings in columns (d) and (e) of Table 4. The second panel refers to models that include lagged, as well as current, leave entitlements. The third controls for all paid leave, whether or not job-protection is provided. The fourth accounts for full-pay weeks of leave. The last panel includes separate regressors for paid and unpaid jobprotected leave. ${ }^{30}$

Table 5

Alternative linear specifications examining the effects of paid leave on infant mortality

\begin{tabular}{lll}
\hline Parental leave regressor & (a) & (b) \\
\hline Job-protected paid leave & $-0.2905(0.0788)$ & $-0.2451(0.0790)$ \\
Job-protected paid leave in current year & $-0.1419(0.1161)$ & $-0.1036(0.1147)$ \\
Job-protected paid leave in previous year $(t-1)$ & $-0.2038(0.1173)$ & $-0.1945(0.1148)$ \\
All paid leave & $-0.3027(0.0912)$ & $-0.3156(0.0899)$ \\
Full-pay weeks of leave & $-0.3374(0.1043)$ & $-0.2749(0.1030)$ \\
Job-protected paid leave & $-0.2905(0.0789)$ & $-0.2422(0.0791)$ \\
Job-protected unpaid leave & $-0.0048(0.0385)$ & $0.0331(0.0388)$ \\
Supplemental regressors & No & Yes \\
\hline
\end{tabular}

See note on Table 4. Each panel refers to a separate series of regressions. All models include year and country dummy variables, country-specific time trends, and the "standard" regressors included in columns (d) of Table 4. "All Paid Leave" refers to paid entitlements, whether or not job-protection is provided. "Full-Pay Weeks of Leave" is calculated as the number of weeks of job-protected leave multiplied by the estimated wage replacement rate. "Unpaid" leave is set to its 1988 value from 1989-1994. Weeks of parental leave are divided by 100 throughout the table. "Supplemental Regressors" include the fertility rate and female employment-to-population ratio.

The negative relationship between paid leave and infant mortality persists across specifications. There appears to be a stronger long-run than short-run effect, as evidenced by the negative coefficient on lagged leave rights. This is logical since the regulations sometime change in the middle of a calendar year, the leave period may span years, and the adjustment to any policy change may be gradual. ${ }^{31}$ The estimated impact of all paid leave (with or without job-protection) or full-pay weeks is marginally larger than that of job-protected leave. More impressive is the overall consistency of results - a 10 -week increase in paid leave is predicted to reduce infant mortality rates by between $2.5 \%$ and $3.4 \%$. By contrast, unpaid leave is unrelated to infant mortality, which makes sense if parents are reluctant to take time off work when wages are not replaced.

\subsection{Other health outcomes}

The results for other pediatric outcomes, summarized in Table 6, are entirely consistent with those expected if parental leave has a causal effect on children's health. Leave has a small and

\footnotetext{
${ }^{30}$ These regressions are estimated assuming that entitlements to unpaid leave during the 1989-1994 time period are the same as in 1988 .

31 I also estimated models with lead values of leave included, as a crude check of reverse causation. The lead coefficients were small and never approached statistical significance.
} 
statistically insignificant predicted effect on fetal development, as measured by birth weight or perinatal mortality, as anticipated

\begin{tabular}{|c|c|c|}
\hline Health outcome & (a) & (b) \\
\hline Low birth weight & $-0.1032(0.0813)$ & $-0.1122(0.0832)$ \\
\hline Perinatal mortality & $-0.0727(0.0739)$ & $-0.0555(0.0746)$ \\
\hline Neonatal mortality & $-0.1592(0.0988)$ & $-0.1128(0.0992)$ \\
\hline Post-neonatal mortality & $-0.3767(0.1464)$ & $-0.4610(0.1457)$ \\
\hline Child mortality & $-0.3587(0.1218)$ & $-0.3383(0.1223)$ \\
\hline Senior citizen mortality & $-0.0036(0.0356)$ & $0.0028(0.0360)$ \\
\hline Supplemental regressors & No & Yes \\
\hline
\end{tabular}

See notes on Tables 4 and 5. Each panel refers to a separate series of regressions. All equations include year and country dummy variables, country-specific time trends, and the "standard" regressors. The coefficients displayed are for weeks of job-protected paid leave divided by 100 . Low Birth Weight refers to new-borns weighing less than $2500 \mathrm{~g}$, perinatal mortality to stillbirths and deaths within the first week of life, neonatal mortality to deaths in the first 27 days, post-neonatal mortality to those occurring between days 28 and 365 , child mortality indicates fatalities between the first and fifth birthday, and senior citizen mortality to the standardized death rate of persons aged 65 and over. Sample sizes are $258,388,368,368,386$, and 397 for the six outcomes.

since the time off work generally occurs late in the pregnancy and employment may be induced during its early stages. The expected reduction in neonatal mortality is also relatively modest; this is logical given that deaths in the first month of life are primarily determined by health at birth and medical interventions during the period surrounding it. ${ }^{32}$

Conversely, leave entitlements substantially reduce predicted mortality during the post-neonatal period and early childhood. For example, a 10-week extension is predicted to decrease postneonatal deaths by 3.7 to $4.5 \%$ and child fatalities by $3.3 \%$ to $3.5 \%$. At the sample means, these correspond to reductions in the post-neonatal mortality from 4.3 to around 4.1 per thousand live births and a reduction from 2.3 to 2.2 child deaths per thousand. These results make sense. Leave is most likely to result in additional parental time investments during the post-neonatal period. There may also be longer-lasting gains since the job absences sometimes extend beyond 1 year and investments made during the first 12 months could yield future health benefits.

The dependent variable in the sixth panel of the table is the death rate of persons 65 and over. The mortality of this group is likely to be affected by many of the same unobserved factors (e.g. lifestyles or medical technologies) as pediatric outcomes but it is not expected to be strongly influenced by parental leave. ${ }^{33}$ Hence, a substantial "effect" of leave for this outcome would

\footnotetext{
${ }^{32}$ Also, mothers frequently take time off work during the first month after birth, even without leave rights. For example, $73 \%$ of "employed" women with 1-month-old infants were on leave (41\% on paid leave) rather than working in the U.S. during the 1986-1988 period, prior to the passage of federal parental leave legislation (Klerman and Leibowitz, 1994).

${ }^{33}$ Parental leave could improve the health of he elderly, for example by increasing the time available for their adult children to assist them. However, the effect is likely to be small since leave rights are restricted to the period surrounding childbirth, whereas the elderly will frequently need help at other times.
} 
probably be due to confounding factors. However, the results indicate that leave rights are unrelated to senior citizen deaths, suggesting that the econometric specifications adequately control for spurious correlation between parental leave and unobserved factors having general effects on health. This increases our confidence that the estimates for infants and children reflect something other than omitted variables bias.

Fertility rates (female EP ratios) are negatively (strongly positively) and significantly correlated with post-neonatal fatalities. The coefficients (not displayed) imply that an increase in the fertility rate from 1.8 to 2.0 children reduces predicted post-neonatal mortality by $3.7 \%$, while a 10 percentage point decrease in the percentage of women employed does so by $5.5 \%$. The fertility result may reflect economies of scale in raising children. The employment finding is consistent with the possibility that working mothers have less time to invest in them. ${ }^{34}$

\subsection{Nonlinearities}

There are several reasons why the relationship between parental leave and the pediatric health may be nonlinear. First, the proportion of the entitlement actually used may vary with its length. For example, some persons may not be able to afford extended leaves with partial wage replacement. Second, the marginal benefit of time investments in infants may decline with their age. Either factor will induce diminishing returns. Conversely, workers may be able to leave their jobs for short but not long periods, in the absence of a formal mandate, implying that legislation providing brief leaves will have no effect on infant health, whereas benefits will be obtained from lengthier durations.

The form of the nonlinearity may also vary across outcomes. For instance, neonatal mortality is unlikely to be reduced by extensions of postnatal leaves beyond 1 month. Since maternity leave rights typically begin (in Europe) around 6 weeks before birth, this implies that there should be little marginal benefit to leave durations exceeding 10 weeks. Conversely, short entitlements could speed the

\footnotetext{
${ }^{34}$ However, female employment leads to a much smaller predicted increase in child mortality and the fertility coefficient switches sign, suggesting that further analysis is needed to determine how these factors affect child health.
} 
Table 7

Linear spline estimates of the percentage reductions in mortality due to job-protected paid parental leave

\begin{tabular}{|c|c|c|c|c|c|c|c|c|c|c|}
\hline \multirow[t]{2}{*}{$\begin{array}{l}\text { Weeks } \\
\text { of leave }\end{array}$} & \multicolumn{2}{|l|}{$\begin{array}{l}\text { Infant } \\
\text { mortality }\end{array}$} & \multicolumn{2}{|c|}{$\begin{array}{l}\text { Perinatal } \\
\text { mortality }\end{array}$} & \multicolumn{2}{|l|}{$\begin{array}{l}\text { Neonatal } \\
\text { mortality }\end{array}$} & \multicolumn{2}{|c|}{$\begin{array}{l}\text { Post-neonatal } \\
\text { mortality }\end{array}$} & \multicolumn{2}{|l|}{$\begin{array}{l}\text { Child } \\
\text { mortality }\end{array}$} \\
\hline & (a) & (b) & (a) & (b) & (a) & (b) & (a) & (b) & (a) & (b) \\
\hline 10 & 2.1 & 1.1 & 3.0 & 2.9 & 4.0 & 3.4 & -3.0 & -1.8 & -0.8 & -1.0 \\
\hline 20 & 4.1 & 2.1 & 6.0 & 5.7 & 7.8 & 6.7 & -6.1 & -3.6 & -1.5 & -2.1 \\
\hline 30 & 9.0 & 7.2 & 6.7 & 6.6 & 10.1 & 8.8 & 2.3 & 5.1 & 4.1 & 3.9 \\
\hline 40 & 16.5 & 15.7 & 5.2 & 5.5 & 10.9 & 10.0 & 19.4 & 21.8 & 15.1 & 15.7 \\
\hline 50 & 14.0 & 12.1 & 3.3 & -3.0 & 7.9 & 6.0 & 18.7 & 21.9 & 16.0 & 15.2 \\
\hline $\begin{array}{l}p \text {-value: } \\
\text { leave }\end{array}$ & 0.0000 & 0.0000 & 0.0112 & 0.0110 & 0.0097 & 0.0155 & 0.0000 & 0.0000 & 0.0002 & 0.0001 \\
\hline $\begin{array}{l}p \text {-value: } \\
\text { splines }\end{array}$ & 0.0032 & 0.0002 & 0.0066 & 0.0050 & 0.0122 & 0.0106 & 0.0000 & 0.0000 & 0.0029 & 0.0010 \\
\hline
\end{tabular}

The table displays the predicted percentage reduction in mortality associated with the specified weeks of job-protected paid leave, compared to no leave mandate. The estimates are obtained from models that include controls for country and year effects, country-specific time trends, and the "standard" regressors. Specification (b) also holds constant the fertility rate and female employment-to-population ratio. The linear splines are estimated with knots at 25 and 40 weeks. The first $p$-value refers to the null hypothesis that parental leave has no effect on the outcome; the second refers to the null hypothesis that parental leave is linearly related to the dependent variable (i.e. no splines are needed).

return to work and so raise post-neonatal and possibly child mortality, whereas lengthier leave periods could reduce these sources of death. ${ }^{35}$

Nonlinearities are modeled by linear spline specifications with knots at 25 and 40 weeks of leave. Table 7 and Figs. 3 and 4 display estimates of changes in predicted mortality at various leave durations, compared to the case of no entitlement. ${ }^{36}$ The first $p$-value on the table refers to the null hypothesis of no parental leave effect. The second tests whether the inclusion of the splines significantly improves model fit. Once again, all specifications include vectors of country and time dummy variables, country-specific time trends, and the standard regressors. Female EP ratios and fertility rates are also controlled for in column (b) of Table 7 and Fig. 4.

The joint significance of the splines provides strong evidence of nonlinearities and the results are consistent with those expected if parental leave has a causal effect on health. In particular, reductions in predicted perinatal and neonatal

\footnotetext{
35 The reason that rights to short leave may hasten the return to work is that the individual must choose between a brief absence, but with the right to continue in the original position, and a longer time off with eventual reemployment in a new and probably less desirable job. In some cases, it will be worthwhile to accept a shorter leave period so as to avoid the change of employers. See Klerman and Leibowitz (1997) for further discussion.

${ }^{36}$ There is never a significant effect on low birth weight, so these findings are not displayed.
} 


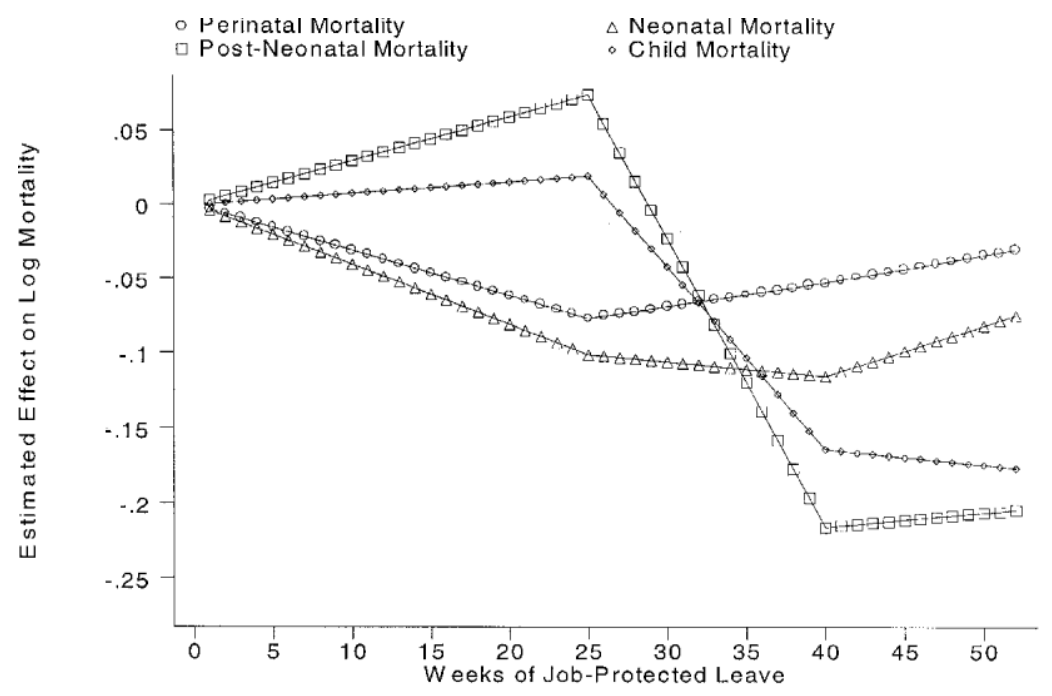

Fig. 3. Parental leave effects in models without supplemental regressors.

mortality are modest (although statistically significant) and concentrated on rights to time off work in the period surrounding birth. By contrast, extended entitlements sharply decrease expected post-neonatal and child mortality, whereas rights to brief leave either have no effect or slightly increase them - 10 weeks of

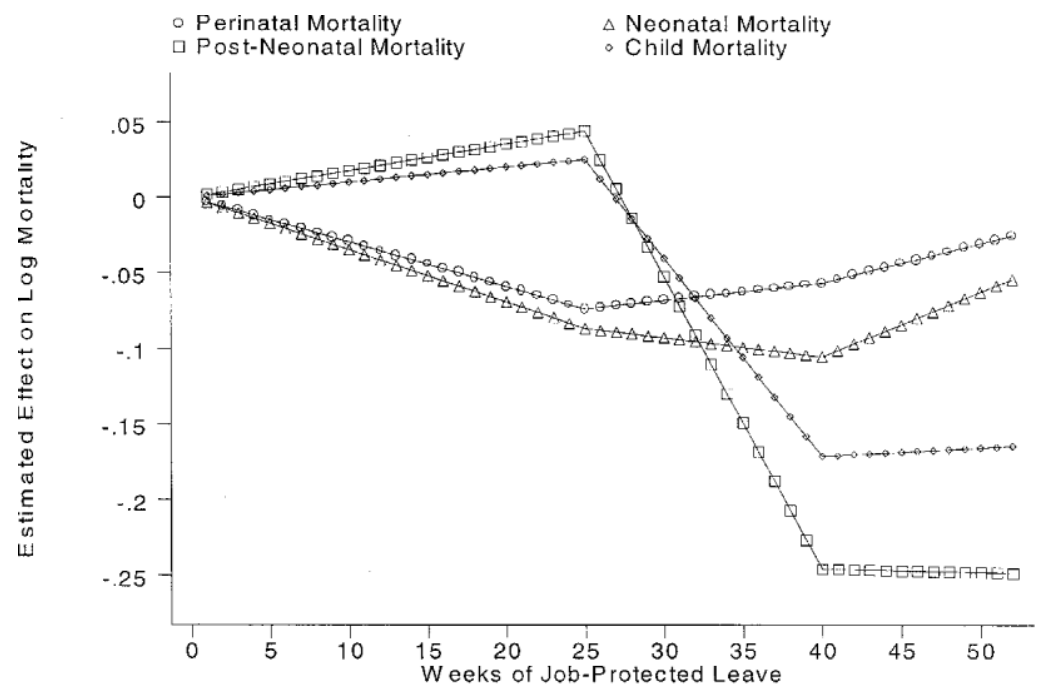

Fig. 4. Parental leave effects in models with supplemental regressors.

parental leave increase expected post-neonatal and child deaths by $2 \%$ to $3 \%$ and $1 \%$, respectively, whereas a 50-week entitlement is predicted to reduce postneonatal fatalities by around $20 \%$ and child mortality by roughly $15 \% .{ }^{37}$ At the sample means, a $20 \%$ reduction in post-neonatal mortality corresponds to a decrease from 4.3 to 3.4 deaths per thousand live births, a $15 \%$ decline in child mortality reflects a drop from 2.3 to 2.0 fatalities per thousand.

\footnotetext{
${ }^{37}$ Similar results were obtained when nonlinearities were modeled by other spline specifications or by including polynomials in leave. For example, with a cubic specification in an equation that includes supplemental regressors, $10,20,30,40$, and 50 weeks of leave reduce predicted post-neonatal mortality by $-4.6 \%,-0.8 \%, 7.3 \%, 15.9 \%$, and $21.9 \%$. This compares to $-1.8 \%,-3.6 \%, 5.1 \%, 21.8 \%$, and $21.9 \%$ decreases in the model with splines.
} 


\section{Plausibility and cost-effectiveness}

The econometric estimates suggest that parental leave entitlements substantially reduce mortality during early childhood. Rights to a year of job-protected paid leave are associated with roughly a $20 \%$ decline in post-neonatal deaths and a 15\% decrease in fatalities occurring between the first and fifth birthdays. Effects of these magnitudes are large but not unreasonable. Post-neonatal and child mortality fell more than $60 \%$ during the sample period, implying that the decreases predicted to result from extensions in leave rights are small compared to those that actually transpired. Also, as noted, even these large percentage reductions imply fairly small absolute changes - a 0.9 per thousand decrease in post-neonatal mortality and a 0.3 per thousand drop in child deaths.

Moreover, there are a variety of mechanisms through which parental leave might yield substantial health benefits. As mentioned, time off work may increase breast-feeding. Roe et al. (1997) estimate that an extra week of postpartum job absence raises the duration of breastfeeding by 3 to 4 days, with an accompanying growth in frequency for those who do so. Although it is difficult to determine the extent to which this might reduce infant deaths, the available evidence suggests the effect could be substantial. For example, a 30 percentage point increase in the fraction of women intending to breast-feed was estimated to decrease post-perinatal death rates by more than 9\%, after controlling for a other risk factors, in Carpenter et al.'s (1983) analysis of a prevention program in Sheffield England. Similarly, Cunningham et al. (1991) find that breast-feeding is associated with a 3.7 per thousand fall in post-perinatal mortality, although some of this may be due to omitted factors. Based on these results, a reasonable guess is that a substantial parental leave entitlement might increase breast-feeding sufficiently to prevent 0.5 to 1.0 post-neonatal deaths per 1000 live births. This represents a $7 \%$ to $14 \%$ reduction in this source of mortality, compared to the 1969 sample average.

Parental leave may also reduce a number of specific health risks during early childhood. To illustrate, Table 8 summarizes the leading causes of infant and young child mortality in the United States in 1996. Not surprisingly, neonatal fatalities are dominated by health problems originating during the prenatal or birth periods. By contrast, parental inputs are likely to play a major role in deterring 
Table 8

Leading causes of neonatal, post-neonatal, and child deaths in the US in 1996

\begin{tabular}{|c|c|c|}
\hline Cause of death & No. of deaths & $\begin{array}{l}\text { Percentage } \\
\text { of deaths }\end{array}$ \\
\hline \multicolumn{3}{|l|}{ Neonatal mortality } \\
\hline 1. Congenital anomalies $(740-759)$ & 4575 & 24.6 \\
\hline $\begin{array}{l}\text { 2. Disorders relating to short gestation/unspecified } \\
\text { low birthweight (765) }\end{array}$ & 3845 & 20.7 \\
\hline 3. Respiratory distress syndrome (769) & 1255 & 6.8 \\
\hline 4. Maternal complications of pregnancy (761) & 1239 & 6.7 \\
\hline 5. Complications of placenta, cord, membranes (762) & 934 & 5.0 \\
\hline 6. Infections specific to perinatal period (771) & 694 & 3.7 \\
\hline 7. Intrauterine hypoxia and birth asphxia (778) & 392 & 2.1 \\
\hline 8. Neonatal hemorrhage (772) & 300 & 1.6 \\
\hline 9. Sudden infant death syndrome (798.0) & 213 & 1.1 \\
\hline 10. Birth trauma $(767)$ & 164 & 0.9 \\
\hline \multicolumn{3}{|l|}{ Post-neonatal mortality } \\
\hline 1. Sudden infant death syndrome (798.0) & 2837 & 28.6 \\
\hline 2. Congenital anomalies (740-759) & 1806 & 18.2 \\
\hline 3. Accidents (E800-E949) & 711 & 7.2 \\
\hline 4. Pneumonia and influenza (480-487) & 398 & 4.0 \\
\hline 5. Homicide (E960-E969) & 285 & 2.9 \\
\hline 6. Septicemia (038) & 199 & 2.0 \\
\hline 7. Respiratory distress syndrome (769) & 107 & 1.1 \\
\hline 8. Bronchitis and bronchiolitis $(466,490-491)$ & 89 & 0.9 \\
\hline 9. Meningitis (320-322) & 81 & 0.8 \\
\hline 10. Malignant neoplasms $(140-208)$ & 72 & 0.7 \\
\hline \multicolumn{3}{|l|}{ Child mortality } \\
\hline 1. Accidents (E800-E949) & 2147 & 36.1 \\
\hline 2. Congenital anomalies (740-759) & 638 & 10.7 \\
\hline 3. Malignant neoplasms $(140-208)$ & 424 & 7.1 \\
\hline 4. Homicide (E960-E969) & 420 & 7.1 \\
\hline 5. Heart disease $(390-398,402,404-429)$ & 217 & 3.6 \\
\hline 6. Pneumonia and influenza $(480-487)$ & 168 & 2.8 \\
\hline 7. Human immunodeficiency virus $(042-044)$ & 147 & 2.5 \\
\hline 8. Septicemia (038) & 83 & 1.4 \\
\hline 9. Benign neoplasms (210-239) & 70 & 1.2 \\
\hline $\begin{array}{l}\text { 10. Certain conditions originating in the perinatal } \\
\text { period }(760-779)\end{array}$ & 60 & 1.0 \\
\hline
\end{tabular}

ICD-9 codes are in parentheses (source: Peters et al., 1998).

many subsequent deaths. For example, four of the five leading causes of postneonatal mortality (Sudden Infant Death syndrome, accidents, pneumonia/influenza, and homicide), accounting for $43 \%$ of fatalities, are almost certainly substantially influenced by the activities of parents. ${ }^{38}$ Similarly, accidents and homicides account for $43 \%$ of child fatalities and several other leading

\footnotetext{
${ }^{38}$ Closer parental involvement is likely to prevent some accidental deaths and may indirectly reduce other sources of fatalities. For example, Sudden Infant Death Syndrome is more than twice as common among infants who sleep prone as for those who do not (Hunt, 1996; Taylor et al., 1996; Oyen et al., 1997). Parental leave could increase the frequency of non-prone sleeping if parents have more energy to monitor sleeping position or are more able to directly observe it. Time off work might also decrease homicides by reducing stress levels in families with young children. Finally, parental leave might lessen the need for child care, which is associated with increased risk of many infectious illnesses (e.g. see Redmond and Pichichero, 1984; Thacker et al., 1992; or Hardy and Fowler, 1993). Parental inputs may even influence mortality due to congenital anomalies to the extent they determine whether the child receives timely medical treatment and other health-preserving investments.
} 
causes (e.g. heart disease, HIV, pneumonia/influenza) may be sensitive to parental involvement. $^{39}$

An obvious policy question is whether the health benefits of parental leave are worth the costs. Towards this end, Appendix A summarizes estimates of the government expenditure on parental leave payments required to save one child's life. ${ }^{40}$ The key assumptions are that: (1) 1 week of parental leave entitlement causes a 0.000038 reduction in the probability of death; (2) each week of leave rights translates into between 0.18 and 0.34 weeks of actual time away from work; (3) annual earnings during the leave period average US\$22,000 (in US\$1997).

Using these assumptions, between 91 and 172 years of parental leave are required to save one life and the cost per life saved is between US\$2.0 and US\$3.8 million(in US\$1997). The latter amounts are within the general range of estimates typically obtained from value-of-life calculations, suggesting that the provision of parental leave may be a cost-effective method of improving health. For example, Viscusi (1992, p. 73) states that most "reasonable estimates of the value of life are clustered in the US\$3 to US\$7 million range'; Manning et al. (1989) use a figure of US\$1.66 million. Adjusting for inflation (using the all-items CPI), these are equivalent to US\$3.5 to US\$8 million and US\$2.15 million, respectively, in 1997 dollars,

Moreover, there are several reasons why this analysis probably understates the benefits of parental leave. First, the measured health improvements are limited to reductions in mortality, whereas many gains may take the form of better health for living children. Second, the advantages for children and families need not be restricted to health (e.g. improved cognition or reductions in household stress). Third, previous research suggests that leave rights may improve the labor market status of women. Fourth, the leave payments may partially offset other types of government spending (e.g. by reducing the utilization of subsidized child care or decreasing public spending on medical services), lowering the true cost of providing it.

Of course, there are many uncertainties associated with the calculations and the analysis that underlies them, some of which could lead to overly favorable assessments. For example, the range of value of life estimates is quite large, with lower valuations sometimes placed on children than adults (since human capital investments have not yet been made) and on individuals in low-income households. ${ }^{41}$ The sample sizes are also quite small, resulting in imprecise estimates in some specifications, and neither eligibility for nor take-up of parental leave has been explicitly modeled. Furthermore, some costs may not have been included. For instance, pediatric health could improve partly because parents on leave have more time to take their young children to receive medical care, the expense of which has not been incorporated into the calculations. Also, it is possible that the health benefits associated with parental leave could be achieved more cheaply through other means, such as by improving the quality of child care or making it easier for employed women to breast-feed.

\footnotetext{
${ }^{39}$ Glied (1999) shows that decreases in deaths due to accidents and unintentional injuries are the most important contributor to the decline in child mortality occurring in the United States since 1970, and that maternal employment predicts higher rates of fatalities due to these sources.

${ }^{40}$ Government expenditures are used since leave payments are received exclusively from the government in most European nations.

${ }^{41}$ Currie and Gruber (1996) provide a careful discussion of these issues, in the context of reductions in infant mortality resulting from Medicaid expansions in the United States.
} 


\section{Conclusion}

This analysis lends credence to the view that parental leave has favorable and possibly costeffective impacts on pediatric health. The most likely reason is that the work absences provide parents with additional time to invest in young children, which may be increasingly crucial given the upward trend in female labor force participation rates. The findings further suggest that parental time is an important but poorly understood input into the production of pediatric health. Ideally, future research will use microdata to verify the results of this study and to identify the mechanisms through which leave entitlements and parental time investments improve the wellbeing of children.

\section{Acknowledgements}

I thank Robert Clark, Janet Currie, Jane Waldfogel, and workshop participants at Humbolt University, North Carolina State University, the National Bureau of Economic Research, University of New Hampshire, New Jersey School of Public Health, Joint Center for Poverty Research, Syracuse University, and the American Economic Association Meetings for helpful comments. Financial support from the National Science Foundation (SES-9876511) is gratefully acknowledged.

\section{Appendix A. Estimates of the cost-per-live saved from parental leave}

Entitlements to 1 week of (additional) paid leave are assumed to decrease neonatal, postneonatal, and child mortality by $0.14 \%, 0.42 \%$, and $0.35 \%$ respectively. ${ }^{42}$ At the sample averages of 8.537, 4.294, and 2.277 deaths per 1000 live births, this implies a reduction of 0.038 fatalities per thousand births, or a 0.000038 decrease in the probability of death. Two estimates are provided of amount of leave actually taken by mothers. The "high" estimate assumes that $42.5 \%$ of pregnant women work throughout their pregnancies and that these individuals use $80 \%$ of available leave benefits, implying 0.34 weeks of actual work absence $(0.8=0.425=0.34)$ per week of entitlement. ${ }^{43}$ These probabilities are based on Swedish data and almost certainly overstate the use of leave because Sweden has relatively high female labor force participation rates prior to birth and "take-up" rates subsequent to it. A second, and probably preferable, "low" estimate assumes that $30 \%$ of pregnant women are employed throughout pregnancy and that this group uses $60 \%$ of available leave benefits. ${ }^{44}$ Under these assumptions a week of leave rights translates into 0.18 weeks of actual use $(0.6 \times 0.3=0.18)$.

The "high" estimate implies that 8947 weeks $(0.34 / 0.000038)$ or 172.1 years of parental leave are required to save one life. Using the "low" estimate, 4137 weeks $(0.18 / 0.000038)$ or 91.1 years

\footnotetext{
${ }^{42}$ These are mid-points of the estimates from specifications (a) and (b) of Table 6.

${ }^{43}$ Sundstom" and Stafford (1992) estimate that 48 (8)\% of Swedish women worked full-time (part-time) immediately before giving birth to their first child and 20 (26)\% prior to later children during the $1988-1990$ period. Assuming that part-time workers were employed half as many hours as those employed full-time and that half of infants were first births (the total fertility rate was 1.96 in 1988), "full-time equivalent" employment was $42.5 \%$ $(0.5(0.48+0.08 / 2)+0.5(0.20+0.26 / 2))$. "Ronsen and Sundstom" (1996) estimate that $81 \%$ of married mothers in Sweden, whose first birth occurred after age 18, used parental leave.

${ }^{44}$ Klerman (1993) estimates that around $70 \%$ of new mothers in the United States, which also has relatively high female participation rates, either do not work at all during pregnancy or quit their jobs prior to giving birth.
} 
are needed. If mothers employed full-time are paid US\$11 per hour for 2000 hours per year, their annual earnings are US\$22,000 (in US\$1997). ${ }^{45}$ This suggests a cost-per-life saved of 3.8 million dollars $(172.1=$ US\$22,000 = US\$3,786,200) using the "high" estimate and 2.0 million dollars $(91.1=$ US $\$ 22,000=$ US $\$ 2,004,200)$ by the "low" estimate.

\section{References}

American Academy of Pediatrics Work Group on Breast-feeding, 1997. Breast-feeding and the use of human milk. Pediatrics 100, 1035-1039.

Averett, S.L., Whittington, L.A., 1997. Does Maternity Leave Induce Births. Lafayette College, mimeo.

Becker, G., 1981. A Treatise on the Family. Harvard Univ. Press, Cambridge.

Blank, R.M., 1994. Introduction. In: Blank, R.M. (Ed.), Social Protection vs. Economic Flexibility. University of Chicago Press, Chicago, pp. 1-19.

Blau, D.M., Guilkey, D.K., Popkin, B.M., 1996. Infant health and the labor supply of mothers. Journal of Human Resources 31, 90-139.

Browning, M., 1992. Children and household economic behavior. Journal of Economic Literature 30, 1434-1475.

Carnegie Task Force on Meeting the Needs of Young Children, 1994. Starting Points: Meeting the Needs of Young Children. Carnegie Corporation of New York, New York.

Carpenter, R.G., Gardner, A., Jepson, M., Taylor, E.M., Salvin, A., Sunderland, R., Emery, J.L., Pursall, E., Roe, J., 1983. Prevention of unexpected infant death: an evaluation of the first seven years of the sheffield intervention programme. The Lancet 83297, 723-727.

Chomitz, V.R., Cheung, L., Lieberman, E., 1995. The role of lifestyle in preventing low birth weight. The Future of Children 5, 121-138.

Corman, H., Grossman, M.I., 1995. Determinants of neonatal mortality rates in the United States. Journal of Health Economics 4, 213-236.

Cunningham, A.S., Jelliffe, D.B., Jelliffe, E.F., 1991. Breast-feeding and health in the 1980s: a global epidemiologic review. The Journal of Pediatrics 118, 659-666.

Currie, J., Gruber, J., 1996. Saving babies: the efficacy and cost of recent changes in the medicaid eligibility of pregnant women. Journal of Political Economy 104, 1263-1296.

Currie, J., Gruber, J., 1997, The Technology of Birth: Health Insurance, Medical Interventions, and Infant Health, National Bureau of Economic Research Working Paper No. 5985.

Dalto, G.C., 1989. A structural approach to women's hometime and experience-earnings profiles: maternity leave and public policy. Population Research and Policy Review 8, 247-266.

Duleep, H.O., 1995. Mortality and income inequality among economically developed countries. Social Security Bulletin 58, 34-50.

Ettner, S.L., 1996. New evidence on the relationship between income and health. Journal of Health Economics 15, 67-85.

Frank, R.G., Strobino, D.M., Salkever, D.S., Jackson, C.A., 1992. Updated estimates of the impact of prenatal care on birthweight outcomes by race. Journal of Human Resources 27, 629-642.

Frisbie, W.P., Forbes, D., Pullum, S.G., 1996. Compromised birth outcomes and infant mortality

\footnotetext{
${ }^{45}$ Waldfogel (1997) indicates that the average hourly earnings of 30 year old women in the U.S. were US\$9.40 in 1991. Adjusting for price changes, using the all-items CPI, this was equivalent to US $\$ 11.08$ per hour in 1997 . These estimates could be adjusted upwards or downwards in a variety of ways. For instance, some fringe benefit costs could be added. On the other hand, wage replacement rates average around $80 \%$ during the leave period. These effects are likely to roughly cancel each other out.
} 
among racial and ethnic groups. Demography 33, 469-481.

Gielen, A.C., Fadden, R.R., O’Campo, P., Brown, H., Paige, D.M., 1991. Maternal employment during the early postpartum period: effects of initiation and continuation of breast-feeding. Pediatrics 87, 298-305.

Glied, S., 1999.The Value of Reductions in Child Injury Mortality in the U.S., National Bureau of Economic Research Working Paper No. 7204.

Grossman, M., 1972. On the concept of health capital and the demand for health. Journal of Political Economy 80, 223-255.

Grossman, M., Joyce, T.J., 1990. Unobservables, pregnancy resolutions, and birth weight production functions in New York City. Journal of Political Economy 98, 983-1007.

Hardy, A.M., Fowler, M.G., 1993. Child care arrangements and repeated ear infections in young children. American Journal of Public Health 83, 1321-1325.

Hunt, C.E., 1996. Prone sleeping in health infants and victims of sudden infant death syndrome. Pediatrics 128, 594-596.

International Labor Office, various years, Legislative Series (International Labor Office Publications, Geneva).

International Labor Office, 1984. Protection of Working Mothers: An ILO Global Survey (19641984), in: Women at Work 2 (International Labor Office Publications, Geneva). pp. 1-71. International Labor Office, various years, Yearbook of Labour Statistics (International Labor Office Publications, Geneva).

Kallman, C., 1996. Wages, Hours, and Employment Effects of State Legislation Mandating Maternity Leave, mimeo, Boston College.

Kamerman, S.B., 1991. Child care policies and programs: an international overview. Journal of Social Issues 47, 179-196.

Klerman, J.A., 1993. Characterizing Leave for Maternity: Modeling the NLSY Data, National Longitudinal Surveys Discussion Paper NLS 95-21, Bureau of Labor Statistics, U.S. Department of Labor.

Klerman, J.A., Leibowitz, A., 1994. The work-employment distinction among new mothers. Journal of Human Resources 29, 277-303.

Klerman, J.A., Leibowitz, A., 1997. Labor supply effects of state maternity leave legislation. In: Blau, F., Erhenberg, R. (Eds.), Gender and Family Issues in the Workplace. Russell Sage Foundation, New York, pp. 65-85.

Klerman, J.A., Leibowitz, A., 1998, FMLA and the Labor Supply of New Mothers: Evidence from the June CPS, mimeo, RAND.

Lindberg, L.D., 1996. Women's decisions about breastfeeding and maternal employment. Journal of Marriage and the Family 58, 239-251.

Liu, K., Moon, M., Sulvetta, M., 1992. International infant mortality rankings: a look behind the numbers. Health Care Financing Review 13, 105-118.

Manning, W.G., Keeler, E.B., Newhouse, J.P., Soss, E.M., Wasserman, J., 1989. The taxes of sin: do smokers and drinkers pay their way. Journal of the American Medical Association 261, 16041609.

McGovern, P., Dowd, B., Gjerdingen, D., Moscovice, I., Kochevar, L., Lohman, W., 1997. Time off work and the postpartum health of employed women. Medical Care 35, 507-521.

Nickell, S., 1997. Unemployment and labor market rigidities: Europe versus North America. Journal of Economic Perspectives 11, 55-74. 
Ondrich, J.C., Spiess, K., Yang, Q., 1996. Barefoot and in a German kitchen: federal parental leave and benefit policy and the return to work after childbirth in Germany. Journal of Population Economics 9,247-266.

Organization for Economic Cooperation and Development, 1995. Long-Term Leave for Parents in OECD Countries. Employment Outlook, July. OECD, Department of Economics and Statistics, Paris, pp. 171-202.

Organization for Economic Cooperation and Development, 1996a, OECD Health Data 96 (OECD, Paris).

Organization for Economic Cooperation and Development, 1996b, Labour Force Statistics: 19741994 (OECD, Paris).

Øyen, N., Markestad, T., Skjærven, R., Irgens, L.M., Helweg-Larsen, K., Alm, B., Norvenius, G., Wennergren, G., 1997. Combined effects of sleeping position and prenatal risk factors in sudden infant death syndrome: the nordic epidemiological SIDS study. Pediatrics 100, 613-621.

Peters, K.D., Kochanek, K.D., Murphy, S.L., 1998. National Vital Statistics Report 47 (November 10).

Prichett, L., Summers, L.H., 1996. Wealthier is healthier. Journal of Human Resources 31, 841868.

Redmond, S.R., Pichichero, M.E., 1984. Hemophilus influenza type B disease: an epidemiologic study with special reference to day-care centers. Journal of the American Medical Association 252, 2581-2584.

Roe, B., Whittington, L.A., Fein, S.B., Teisl, M.F., 1997. Is There Competition Between Breastfeeding and Maternal Employment?, mimeo, Georgetown Public Policy Institute.

"Ronsen, M., Sundstom,“"M., 1996. Maternal employment in Scandinavia: a comparison of the after-birth employment activity of Norwegian and Swedish women. Journal of Population Economics 9, 267-285.

Rosenzweig, M.R., Schultz, T.P., 1983. Estimating a household production function: heterogeneity, the demand for health inputs, and their effects on birth weight. Journal of Political Economy 91, 723-746.

Rosenzweig, M.R., Wolpin, K.I., 1988. Heterogeneity, intrafamily distribution, and child health. Journal of Human Resources 23, 437-461.

Ross, K.E., 1988. Labor Pains: The Effects of the Family and Medical Leave Act on Recent Mothers' Returns to Paid Work After Childbirth, mimeo, Syracuse University.

Ruhm, C.J., 1998. The economic consequences of parental leave policies: lessons from Europe. Quarterly Journal of Economics 113, 285-317.

Ruhm, C.J. forthcoming, Are Recessions Good For Your Health?, Quarterly Journal of Economics.

Ruhm, C.J., 1997. Policy watch: the family and medical leave act. Journal of Economic Perspectives 11, 175-186.

Ruhm, C.J., Teague, J.L., 1997. Parental leave policies in Europe and North America. In: Blau, F., Erhenberg, R. (Eds.), Gender and Family Issues in the Workplace. Russell Sage Foundation, New York, pp. 133-156.

Ryan, A.S., Martinez, G.A., 1989. Breast-feeding and the working mother: a profile. Pediatrics 83, 524-531.

Siebert, H., 1997. Labor market rigidities: at the root of unemployment in Europe. Journal of Economic Perspectives 11, 37-54.

Spalter-Roth, R.M., Hartman, H.I., 1990. Unnecessary Losses: Costs to Americans of the Lack of Family and Medical Leave. Institute for Women's Policy Research, Washington, D.C. 
Sundstom," M., Stafford, F.P., 1992. Female labour force participation, fertility, and public policy in Sweden. European Journal of Population 8, 199-215.

Taylor, J.A., Krieger, J.W., Reay, D.T., Davis, R.L., Harruff, R., Cheney, L.K., 1996. Prone sleep position and the sudden infant death syndrome in King County Washington: a case-control study. The Journal of Pediatrics 128, 626-630.

Teague, J.L., 1993. An International Analysis of the Effects of Family Leave Policies on Employment and Labor Force Participation, unpublished M.A. thesis, University of North Carolina Greensboro.

Thacker, S.B., Addiss, D., Goodman, R.A., Holloway, B., Spencer, H.C., 1992. Infectious diseases and injuries in child day care: opportunities for healthier children. Journal of the American Medical Association 268, 1720-1726.

U.S. Social Security Administration, various years, Social Security Programs Throughout the World (U.S. Government Printing Office).

Viscusi, M.K., 1992. Fatal Tradeoffs: Public and Private Responsibilities for Risk. Oxford Univ. Press, New York.

Waldfogel, J., 1999. The impact of the family and medical leave act. Journal of Policy Analysis and Management 18, 281-302.

Waldfogel, J., 1997. Working mothers then and now: a cross-cohort analysis of the effects of maternity leave on women's pay. In: Blau, F., Erhenberg, R. (Eds.), Gender and Family Issues in the Workplace. Russell Sage Foundation, New York, pp. 92-126.

Warner, G.L., 1995. Prenatal care demand and birthweight production of black mothers. American Economic Review 85, 132-137.

Winegarden, C.R., Bracy, P.M., 1995. Demographic consequences of maternal-leave programs in industrialized countries: evidence from fixed-effect models. Southern Economic Journal 61, $1020-1035$.

World Health Organization, Health for All Data Base: European Region, 1997, downloaded from http:/www.who.dk/country.htm. 